\title{
Study on Knowledge Level and Association with Socio-Economic Characteristics of Okra Growers in Western Uttar Pradesh, India
}

\author{
Bhuvnesh Kumar, Dan Singh*, D.K. Singh, R.N. Yadav, and V.K. Singh \\ Department of Agricultural Extension and Communication Sardar Vallabhbhai Patel University \\ of Agriculture and Technology, Meerut, U.P., India \\ *Corresponding author
}

\section{A B S T R A C T}

The present study was conducted in Meerut district of Western Uttar Pradesh to

Keywords

Okra growers and association characteristics.

Article Info

Accepted:

23 June 2017

Available Online:

10 July 2017 know the knowledge level and association with socio-economic characteristics of the okra growers, it was found that most of the okra grower were having fair knowledge about okra cultivation practices. The young age group 12.50 percent respondents had good knowledge about improve package of practices of okra cultivation and associated okra cultivation, higher educated okra growers 35 percent were having fair knowledge level, more active, interested in okra cultivation and associated okra cultivation, the backward caste okra growers were having fair and good level of knowledge in okra cultivation i.e. 40 percent and 22.50 percent, the marginal farmers were having fair and good level of knowledge in okra cultivation i.e. 17.75 percent and 11.25 percent and those okra growers income upto one lakh per annual, they were having good and fair level of knowledge in okra cultivation and associated okra cultivation.

\section{Introduction}

India is the second largest producers of vegetables in the world next to china with 2.8 per cent of total cropped area under vegetables. The total cultivated area of vegetables in India was 9542.23 thousand ha. and production of 169478.23 thousand million tons in 2014-15. Our country has progressed significantly during the past six decades in developing high yield verities/hybrids of different vegetables with their improved qualities and standardized agro techniques suitable for different agro-climatic conditions. Out per capita consumption has increased from 80-175 g./day. However the present per capita consumption of vegetables per day is only $175 \mathrm{~g}$. Which is below the recommended requirement of $300 \mathrm{~g}$. keeping in view the above facts, our aimed is study on knowledge level and association with socioeconomic characteristics of the okra growers.

\section{Materials and Methods}

The district Meerut comprises of twelve blocks, out of which two blocks i.e Kharkhonda and Daurala were selected randomly. From each block four villages were selected randomly. Thus, the total eight villages were selected for the investigation. Village wise list of okra growers were 
obtained from the Kharkhonda and Daurala block of Meerut district. The revenue villages were arrange in descending order based on the number of okra growers, four villages were randomly selected from each block. From each village ten respondents were selected randomly. Thus the total sample size was of 80 respondents for the investigation.

The data were collected through personal interview with the help of survey schedule, data analyzed, tabulated and find out the percentage of the okra growers.

\section{Results and Discussion}

The data presented in table 1 , reveals that the majority of 50.00 percent okra growers were having fair knowledge about okra cultivation practices, followed by 35.00 percent okra growers were having good knowledge and the remaining 15.00 percent okra growers were having poor knowledge about okra cultivation practices.

It is clear from the table 2, that the majority of 43.75 percent okra growers were medium age group (36-50 year), out of which 23.75 percent okra growers were having fair knowledge, 11.25 percent okra growers were having good knowledge and 8.75 percent okra growers were having poor knowledge. 33.75 percent okra growers were old age group (above 50 year), out of which 20.00 percent okra growers were having fair knowledge, 8.75 percent okra growers were having good level of knowledge and 5.00 percent okra growers were having poor knowledge.

22.50 percent okra growers were young age group (18-35 year) out of which 12.50 percent okra growers were having good knowledge, 6.25 percent okra growers were having fair knowledge and 3.75 percent okra growers were having poor knowledge. The young age group of respondents had more knowledge and associated okra cultivation. The data reported in table 3 , reveals that the majority of 35.00 percent okra growers were having intermediate education out of which 15.00, 13.75 and 6.25 percent okra growers were having fair, good and poor knowledge level, followed by 20.00 percent were having middle school education out of which 10.00 , 6.25 and 3.75 percent okra growers were having Fair, good and poor knowledge level, 13.75 percent okra growers were having high school education out of which 8.75, 2.50 and 2.50 percent okra growers were having fair, good and poor knowledge level, 11.25 percent okra growers were illiterate out of which 5.00, 5.00 and 1.25 percent okra growers were having fair, poor and good knowledge level, 12.50 percent okra growers were having up to graduate education and above education of which $6.25,5.00$ and 1.25 percent okra growers were having Fair, good and poor knowledge level, 7.50 percent okra growers were having primary school education out of which 5.00, 1.25 and 1.25 percent okra growers were having fair, good and poor knowledge level respectively. The higher educated respondents had more knowledge and associated okra cultivation.

It is evident table 4, indicated that the majority of 76.25 percent okra growers were belonging to backward caste, out of which $40.00,22.50$ and 13.75 percent okra growers were having fair, good and poor knowledge level, followed by 11.25 percent okra growers were belonging to the general caste, out of which 5.00, 3.75 and 2.50 okra growers were having fair, good and poor knowledge level, 7.5 percent were belonging to minorities, out of which $3.75,2.50$ and 1.25 percent okra growers were having good, fair and poor knowledge level and the remaining that 5.00 percent were belonging to Schedule caste/Schedule tribes out of which 2.50,1.25 and 1.25 percent okra growers were having poor, good and fair knowledge level 
respectively. The backward caste okra growers were having highest percentage of fair and good level of knowledge in okra cultivation. The backward caste respondents had more knowledge and associated okra cultivation.

It is evident from the table 5, revealed that the majority of 36.25 percent okra growers were belonging to marginal size of land holing out of which $17.75,11.25$ and 7.50 percent okra growers were having fair, good and poor level of knowledge, followed by 25.00 percent okra growers were belonging to small size of land holding out of which $13.75,7.50$ and 3.75 percent okra growers were having fair, good and poor level of knowledge, 20.00 percent okra growers were belonging to medium size of land holding out of which 10.00, 6.25 and 3.75 percent okra growers were having fair, good and poor level of knowledge, 18.75 percent okra growers were belonging to large size of land holding out of which $7.50,6.25$ and 5.00 percent okra growers were having fair, good and poor level of knowledge and the remaining respectively. The marginal farmers had more knowledge and associated okra cultivation.

Table.1 Knowledge of okra growers regarding okra cultivation package of practices

\begin{tabular}{|c|c|c|c|c|}
\hline Variable & Particulars & Score Range & Respondents & Percentage \\
\hline \multirow{3}{*}{$\begin{array}{l}\text { Level of } \\
\text { Knowledge }\end{array}$} & 1. Poor & $0-19$ & 12 & 15.00 \\
\hline & 2. $\quad$ Fair & $20-38$ & 40 & 50.00 \\
\hline & 3. Good & $39-56$ & 28 & 35.00 \\
\hline
\end{tabular}

Table.2 Association between knowledge and age of the okra growers regarding Improved packages of practices of okra cultivation

\begin{tabular}{|c|c|c|c|c|c|c|c|}
\hline \multirow{2}{*}{ Particulars } & \multicolumn{6}{|c|}{ Level of knowledge } & \multirow{2}{*}{ Percentage } \\
\cline { 2 - 8 } & \multicolumn{2}{|c|}{ Poor } & \multicolumn{2}{c|}{ Fair } & \multicolumn{2}{c|}{ Good } & \\
\cline { 2 - 7 } & Freq. & \% & Freq. & \% & Freq. & \% & \\
\hline Young (18-35year) & 3 & 3.75 & 5 & 06.25 & 10 & 12.50 & 22.50 \\
\hline Medium (36-50year) & 7 & 8.75 & 19 & 23.75 & 9 & 11.25 & 43.75 \\
\hline Old (Above 50 year) & 4 & 5.00 & 16 & 20.00 & 7 & 08.75 & 33.75 \\
\hline
\end{tabular}

Table.3 Association between knowledge and education level of the okra growers regarding improved package of practices of okra cultivation

\begin{tabular}{|c|c|c|c|c|c|c|c|c|}
\hline \multirow[t]{3}{*}{ Variable } & \multirow[t]{3}{*}{ Particulars } & \multicolumn{6}{|c|}{ Level of knowledge } & \multirow[t]{3}{*}{ Percentage } \\
\hline & & \multicolumn{2}{|c|}{ Poor } & \multicolumn{2}{|c|}{ Fair } & \multicolumn{2}{|c|}{ Good } & \\
\hline & & Freq. & $\%$ & Freq. & $\%$ & Freq. & $\%$ & \\
\hline \multirow{6}{*}{$\begin{array}{r}\text { Level of } \\
\text { education }\end{array}$} & Illiterate & 4 & 5.00 & 4 & 05.00 & 1 & 01.25 & 11.25 \\
\hline & Primary school & 1 & 1.25 & 4 & 05.00 & 1 & 01.25 & 07.50 \\
\hline & Middle school & 3 & 3.75 & 8 & 10.00 & 5 & 06.25 & 20.00 \\
\hline & High school & 2 & 2.50 & 7 & 08.75 & 2 & 02.50 & 13.75 \\
\hline & Intermediate & 5 & 6.25 & 12 & 15.00 & 11 & 13.75 & 35.00 \\
\hline & Graduate and above & 1 & 1.25 & 5 & 06.25 & 4 & 05.00 & 12.50 \\
\hline
\end{tabular}


Table.4 Association between caste and knowledge level of the okra growers regarding Improved package of practices of okra cultivation

\begin{tabular}{|c|c|c|c|c|c|c|c|c|}
\hline \multirow[t]{3}{*}{ Variable } & \multirow[t]{3}{*}{ Particulars } & \multicolumn{6}{|c|}{ Level of knowledge } & \multirow[t]{3}{*}{ Percentage } \\
\hline & & \multicolumn{2}{|c|}{ Poor } & \multicolumn{2}{|c|}{ Fair } & \multicolumn{2}{|c|}{ Good } & \\
\hline & & $\mathbf{F}$ & $\%$ & $\mathbf{F}$ & $\%$ & $\mathbf{F}$ & $\%$ & \\
\hline \multirow{4}{*}{ Caste } & Schedule caste/Schedule tribes & 2 & 02.50 & 1 & 01.25 & 1 & 1.25 & 05.00 \\
\hline & Backward caste & 11 & 13.75 & 32 & 40.00 & 18 & 22.50 & 76.25 \\
\hline & General & 2 & 02.50 & 4 & 05.00 & 3 & 03.75 & 11.25 \\
\hline & Minorities & 1 & 01.25 & 2 & 02.50 & 3 & 03.75 & 07.50 \\
\hline
\end{tabular}

Table.5 Association between land holding size and knowledge level of the okra growers regarding improved package of practices of okra cultivation

\begin{tabular}{|c|c|c|c|c|c|c|c|c|}
\hline \multirow[t]{3}{*}{ Variable } & \multirow[t]{3}{*}{ Particulars } & \multicolumn{6}{|c|}{ Level of knowledge } & \multirow[t]{3}{*}{ Percentage } \\
\hline & & \multicolumn{2}{|c|}{ Poor } & \multicolumn{2}{|c|}{ Fair } & \multicolumn{2}{|c|}{ Good } & \\
\hline & & $\mathbf{F}$ & $\%$ & $\mathbf{F}$ & $\%$ & $\mathbf{F}$ & $\%$ & \\
\hline \multirow{4}{*}{$\begin{array}{l}\text { Size of land } \\
\text { holding }\end{array}$} & Marginal (below 1 ha.) & 6 & 7.50 & 14 & 17.75 & 9 & 11.25 & 36.25 \\
\hline & Small (1-2 ha.) & 3 & 3.75 & 11 & 13.75 & 6 & 7.50 & 25.00 \\
\hline & Medium (2-4 ha.) & 3 & 3.75 & 8 & 10.00 & 5 & 6.25 & 20.00 \\
\hline & Large (above 4 ha.) & 4 & 5.00 & 6 & 7.50 & 5 & 6.25 & 18.75 \\
\hline
\end{tabular}

Table.6 Association between annual income and knowledge level of the okra growers regarding improved package of practices of okra cultivation

\begin{tabular}{|c|c|c|c|c|c|c|c|c|}
\hline \multirow[t]{3}{*}{ Variable } & \multirow[t]{3}{*}{ Particulars } & \multicolumn{6}{|c|}{ Level of knowledge } & \multirow[t]{3}{*}{ Percentage } \\
\hline & & \multicolumn{2}{|c|}{ Poor } & \multicolumn{2}{|c|}{ Fair } & \multicolumn{2}{|c|}{ Good } & \\
\hline & & $\mathbf{F}$ & $\%$ & $\mathbf{F}$ & $\%$ & $\mathbf{F}$ & $\%$ & \\
\hline \multirow{4}{*}{$\begin{array}{l}\text { Annual } \\
\text { Income }\end{array}$} & Below Rs. 50,000/- & 2 & 02.50 & 7 & 8.75 & 1 & 01.25 & 12.50 \\
\hline & Rs. 50,001-1,00,000/- & 8 & 10.00 & 12 & 15.00 & 14 & 17.50 & 42.50 \\
\hline & Rs. $1,00,001-1,50,000 /-$ & 2 & 02.50 & 8 & 10.00 & 5 & 06.25 & 18.75 \\
\hline & Above Rs. 1,50,000/- & 4 & 05.00 & 11 & 13.75 & 6 & 07.50 & 26.25 \\
\hline
\end{tabular}

It is clear from the table 6 , that the majority of 42.50 percent okra growers were belonging to the income group of above Rs. 1,50,000/- per annual out of which $17.50,15.00$ and 10.00 percent okra growers were having good, fair and poor level of knowledge, followed by 26.25 percent okra growers were belonging to the income group of Rs. $50.001-1,00,000 /-$ out of which $13.75,7.50$ and 5.00 percent okra growers were having fair, good and poor level of knowledge, 18.75 percent okra growers were belonging to the income group of Rs. 1,00,001 - 1,50,000/- out of which $10.00,6.25$ and 2.50 percent okra growers were having fair, good and poor level of knowledge and the remaining 12.50 percent okra growers were belonging to the income group below Rs. 50,000/- per annual, out of which $8.75,2.50$ and 1.25 percent okra growers were having fair, poor and good level of knowledge regarding okra cultivation respectively. Those farmers having income upto Rs. one lakh there knowledge were higher and associated okra cultivation. 
Farhad et al., (2005) reported that majority (68 percent) of the respondents had medium knowledge regarding integrated pest management in vegetable cultivation, Sardana et al., (2005) reported that none of the farmers was aware about the integrated pest management in vegetable cultivation and their benefits, Rao et al., (2007) reported that 31 percent the vegetable growers had high level of knowledge regarding integrated pest management in vegetable cultivation, Ramachandra et al., (2008) revealed that majority of vegetable growers had high to medium level of knowledge with respect to nutrient management practices in cabbagepotato cropping system, Raj et al.,(2009) reported that poor knowledge and adoption of good variety, soil, seed \& seedling treatment, fertilizer management with use of micronutrient, plant protection measures and post-harvest operation were observed with the vegetable growers, Singh et al., (2009) reported that most of the cole crops growers were having high knowledge about selection $\&$ preparation of main field, nursery and irrigation management and most of the cole crops growers were having low level of knowledge regarding varieties, seed treatment, application of fertilizers and plant protection measurement, Choudhary and Ray (2010) reported that (1) a majority of the respondents had low knowledge index and low level of adoption of the IPM techniques, (2) age, caste, educational status, total monthly income of the family positively associated regarding the IPM techniques in the selected vegetable cultivation, Manjari (2015) reported that the respondents had good knowledge only in one component i.e. harvesting of okra and cucumber however, in rest of the components i.e. plant protection measures, irrigation weeding, manure \& fertilizer application, varieties, seed sowing and soil and field preparation had low knowledge level.
It can be concluded from the above study that the majority of okra grower were having fair knowledge about okra cultivation practices. The young age group of respondents had good knowledge about improve package of practices of okra cultivation and associated okra cultivation, higher educated okra growers were having fair knowledge level, more active, interested in okra cultivation and associated okra cultivation, the backward caste okra growers were having fair and good level of knowledge in okra cultivation, the marginal farmers were having fair and good level of knowledge in okra cultivation and those okra growers income upto one lakh they were having very good and fair level of knowledge in okra cultivation and associated okra cultivation.

\section{References}

Anonymous (2014-15). Data Book of National Horticulture Board

A.S. Lad, V.S. Bedre and S.D. Wangikar (2010) Knowledge of the okra growers about recommended cultivation practices of okra, College of Agriculture, Marathawada Agricultural University, Parbhani - 431 402, India Agric. Sci. Digest., 30 (4) : 296 - 298,

Farhad, A. K. M., Kashem, M. A. and Miah, M. A. M. (2005). Knowledge of rural women on IPM in vegetable cultivation. Bangladesh Journal of Training and Development; 18(1/2):27-36.

M. Bhavya Manjari (2015) Knowledge of the respondents about vegetable cultivation practices, International Journal of Advanced Research in Management and Social Sciences ISSN: 2278-6236.

Rao, L. R., Shivamurthy, M., Shailaja, Hittalamani and Lakshminarayan, M. T. (2007). Knowledge of vegetable growers regarding Integrated Pest Management practices. Research on Crops; 8(1):248-251. 
Ramachandra, K. V., Madhuprasad, V. L. and Shivanandam, V. N. (2008). Knowledge level of vegetable growers on nutrient management practices in cabbagepotato cropping system in district Kolar. International Journal of Agricultural Sciences. 4(2):421-424.

Raj, R. K., Pradhan, L., Ray, P. and Behera, M. (2009). Vegetables cultivation growers knowledge and adoption of management practices. Journal of Interacademicia; 13(4):501-506.
Sardana, H.R., Kadu, L.N., Singh, D.K. and Singh, R.V. (2005). Knowledge of pest management practices. Indian Journal of Extension Education. 41(1 \& 2): 8083.

Singh, D, Singh, V.K., Yadav, R.N. and Singh, D.K. (2009). Assessment of knowledge level of the cole crops growers with respect to cole crops production technology. Prog. Agric. 9 (1): 104-108.

\section{How to cite this article:}

Bhuvnesh Kumar, Dan Singh, D.K. Singh, R.N. Yadav, and Singh, V.K. 2017. Study on Knowledge Level and Association with Socio-Economic Characteristics of Okra Growers in Western Uttar Pradesh, India. Int.J.Curr.Microbiol.App.Sci. 6(7): 2513-2518. doi: https://doi.org/10.20546/ijcmas.2017.607.296 